\title{
The impact of the renminbi real exchange rate on ASEAN disaggregated exports to China
}

\begin{abstract}
Previous studies that focused on the impact of the Renminbi (RMB) on China's trade performance have not paid much attention to how the RMB affects China's main supply chain countries, the Association of Southeast Asian Nations (ASEAN). Our paper fills this gap by addressing the nexus of production fragmentation and product technology based on a panel dynamic ordinary least square (DOLS) estimator. We documented three findings. First, income elasticity is positive and significant in all export categories and increases with higher technology products. Second, consistent with the literature, we find that the RMB real exchange rate has a significant positive impact on ASEAN total exports to China and that the exports of high-tech and medium-tech finished goods, as well as the parts and components exports, contribute to this effect. Third, the RMB effect on disaggregated exports by technology level is mixed: For finished goods exports, higher technology exports are more sensitive to RMB depreciation, which is consistent with the income effect, while for parts and components exports, the lower technology exports actually have greater exposure to RMB depreciation, which is possibly due to the price effect and the recent production relocations of MNCs in the ASEAN region to China and Vietnam.
\end{abstract}

Keyword: Export; Exchange rate; ASEAN; Technology; Parts and components; DOLS 